\title{
Creating and using industry-based problem-based learning challenges in photonics: lessons learned
}

Judith Donnelly, Michele Dischino, Fenna Hanes, Nicholas Massa

Judith Donnelly, Michele Dischino, Fenna Hanes, Nicholas Massa, "Creating and using industry-based problem-based learning challenges in photonics: lessons learned," Proc. SPIE 9666, 11th Education and Training in Optics and Photonics Conference, 966611 (5 June 2009); doi: 10.1117/12.2208042

SPIE Event: Eleventh International Topical Meeting on Education and Training in Optics and Photonics, 2009, St. Asaph, United Kingdom 


\title{
Creating and Using Industry-Based Problem-Based Learning Challenges in Photonics: Lessons Learned
}

\author{
Judith Donnelly \\ Three Rivers Community College, 574 New London Turnpike, Norwich, CT 06030 USA \\ Michele Dischino \\ Central CT State University, 1615 Stanley Street, New Britain, CT 06050 USA \\ Fenna Hanes \\ New England Board of Higher Education, 45 Temple Place, Boston, MA 02111 USA \\ Nicholas Massa \\ Springfield Technical Community College, Armory Square, Springfield, MA 01102 USA
}

\begin{abstract}
Problem-based learning (PBL) is an educational approach whereby students learn course content by actively and collaboratively solving real-world problems presented in a context similar to that in which the learning is to be applied. Project PHOTON PBL, in collaboration with photonics industry and research university partners, created eight interdisciplinary multi-media Challenges to be used in high school and community college math, science and technology courses. Each Challenge was recorded on location and features the scientists, engineers and technicians who originally solved the problem engaged in authentic problem solving. In this paper we describe the evolution of the development of the Challenges and we provide instructions on creating a Challenge and using it in the classroom to enhance student learning.
\end{abstract}

\section{INTRODUCTION}

Since 1995, the New England Board of Higher Education (Boston, MA) has been developing curriculum and materials and offering professional development to high school teachers and college faculty in optics/photonics with support from the Advanced Technological Education program of the National Science Foundation (NSF/ATE). Projects FOTEP (Fiber Optic Technology Education Project), PHOTON and PHOTON2 resulted in the creation of a textbook, laboratory kit, an experiment manual, online instructional videos and a hands-on web-based teacher professional development course, Introduction to Photonics. As the first three PHOTON projects progressed, the PHOTON team realized that developing exemplary materials was not sufficient; it is equally important to address the teaching and learning process if the materials are to be used successfully in the classroom.

As part of an engineering or science team, technicians must apply their knowledge of optics, electronics and related technologies to solve "real-world" problems. Yet there is very little about typical lecture-based instruction followed by back of the chapter problems and stand alone laboratories that prepares students for the ill-structured open-ended problems they will face on the job. The fourth PHOTON project, PHOTON PBL, was designed to meet the need for instructional materials that have been shown to address the way students learn best while at the same time requiring that they engage in the critical thinking and problem-solving skills they will need to be successful lifelong learners. To accomplish this task, eight multimedia problem-based learning challenges were created, based on actual problems solved by industry and research universities. At weeklong summer workshops in 2007 and 2008, 48 high school and college educators were introduced to the PBL method of instruction and the PHOTON PBL Challenges. During the following academic year, teachers field-tested the Challenges in their own classrooms. Evaluation surveys of students and teachers were used to refine the Challenges and develop new resources for problem solving and assessment. 


\section{WHAT IS PROBLEM-BASED LEARNING?}

PBL was developed in the 1970s for use in medical education, and it teaches students content and enhances critical thinking through the collaborative solving of authentic real-world problems. Unlike project-based learning that requires students complete a project after they have mastered the material, in problem-based learning students master the material in the process of solving a problem. Students are active participants in their own learning, placed in a situation where problem parameters are not well defined and more than one outcome is possible.

PBL usually involves four steps: problem analysis, self-directed learning, brainstorming discussions and solution testing (see Figure 1). In the first step, students are presented with a problem and asked to identify what is known and unknown and if any constraints apply. After working together to analyze the problem and its requirements, students then create their own plan for acquiring the knowledge necessary to solve the problem. The instructor acts as a facilitator as students seek out their own resources. Once the self-directed learning phase is complete, the group reconvenes to brainstorm possible solutions and then to evaluate the chosen solution. If the solution does not in fact address all the parameters of the original problem, the cycle is repeated. When an acceptable solution is found, it is presented for peer review and comment.

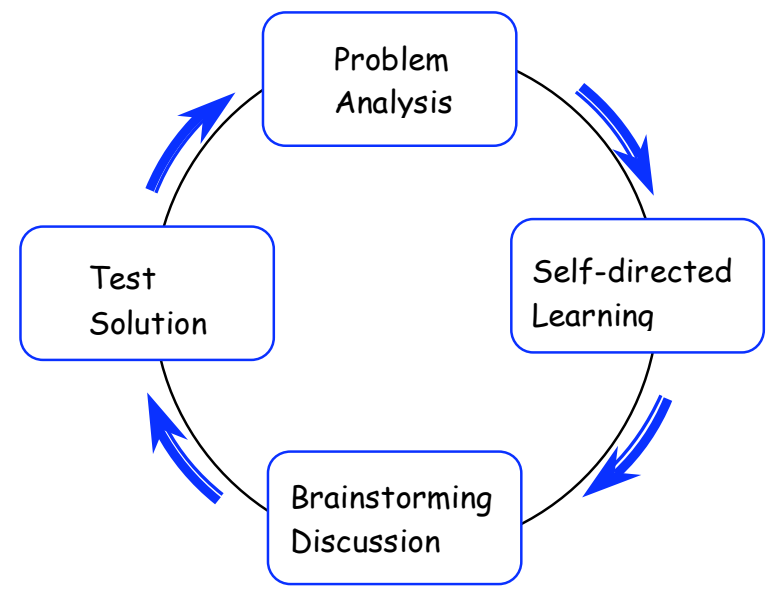

Figure 1. The PBL problem solving cycle

Research has shown that compared to lecture-based instruction, PBL improves student understanding and retention of ideas, critical thinking, communication and problem-solving skills. In addition, they are better able to adapt learning to new situations, an essential skill for working technicians and life-long learning. ${ }^{1,2}$

\section{THE PHOTON PBL CHALLENGES}

\subsection{Creating the challenges}

The first step in developing real-world optics/photonics challenges was to enlist the aid of industry and research university collaborators who had potential problems that would make engaging PBL Challenges. Appropriate problems are open-ended with several possible solutions, stimulate the interest of students, are interdisciplinary in nature, and address several optics/photonics topics normally covered in a first semester course at the community college level. The problem has to have been solved by the organization so that students can compare and contrast their solutions to the organization's solution. Such comparison often leads students to the realization that the most technically advanced solution is not necessarily the best solution if it is cost prohibitive or exceeds time constraints. Contacts from the PHOTON projects' advisory committees, OSA, SPIE, and companies that served as faculty internship hosts for previous PHOTON projects were all contacted for possible problems suitable for adaptation as PBL Challenges.

Four companies, three research universities and one trade organization provided material for the PHOTON PBL Challenges. An effort was made to include Challenges covering diverse applications from medicine to material processing to energy efficiency while at the same time including as many optics topics as possible. Table 1 lists the eight PHOTON PBL Challenges along with a brief description of each. 


\begin{tabular}{|c|c|c|c|}
\hline Challenge Title & Partner Organization & What the challenge is about & Photonics Principles \\
\hline $\begin{array}{l}\text { Blinded by the } \\
\text { Light }\end{array}$ & $\begin{array}{l}\text { In collaboration with the } \\
\text { International Laser } \\
\text { Display Association } \\
\text { (Orlando, FL) }\end{array}$ & $\begin{array}{l}\text { Can an airplane pilot be } \\
\text { permanently injured by a green } \\
\text { laser pointer? What laser hazards } \\
\text { does the pilot face? }\end{array}$ & $\begin{array}{l}\text { - Laser safety } \\
\text { - Irradiance } \\
\text { - Divergence } \\
\text { - MPE } \\
\text { - Glare, flashblindness }\end{array}$ \\
\hline Hiking 911 & $\begin{array}{l}\text { Penn State University } \\
\text { Electo-Optics Center } \\
\text { (Freeport, PA) }\end{array}$ & $\begin{array}{l}\text { Two boys are lost in deep woods } \\
\text { in rough terrain. Penn State } \\
\text { Electro Optics Center (EOC) } \\
\text { needs to recommend the best } \\
\text { technology to locate them. }\end{array}$ & $\begin{array}{l}\text { - Electromagnetic spectrum } \\
\text { - Thermal imaging } \\
\text { - Pixel size } \\
\text { - Resolution }\end{array}$ \\
\hline $\begin{array}{l}\text { Stripping with } \\
\text { Light, Fantastic! }\end{array}$ & $\begin{array}{l}\text { PhotoMachining } \\
\text { (Pelham, NH) }\end{array}$ & $\begin{array}{l}\text { PhotoMachining needs to develop } \\
\text { a process for stripping the coating } \\
\text { from } 50 \text { micron wire for a medical } \\
\text { device. }\end{array}$ & $\begin{array}{l}\text { - } \mathrm{CO}_{2} \text { and excimer laser } \\
\text { characteristics } \\
\text { - Laser power measurement } \\
\text { - Optical system design } \\
\text { - Laser material processing }\end{array}$ \\
\hline $\begin{array}{l}\text { DNA Microarray } \\
\text { Fabrication }\end{array}$ & $\begin{array}{l}\text { Boston University } \\
\text { Photonics Research } \\
\text { Center } \\
\text { (Boston, MA) }\end{array}$ & $\begin{array}{l}\text { Boston University graduate } \\
\text { students need to determine the } \\
\text { best starting exposure time for a } \\
\text { DNA microarry fabricator. }\end{array}$ & $\begin{array}{l}\text { - Radiometry } \\
\text { - Absorption spectra } \\
\text { - Optical power budget } \\
\text { - Optical system design } \\
\text { - Micromirror arrays }\end{array}$ \\
\hline $\begin{array}{l}\text { High Power Laser } \\
\text { Burn-In Test }\end{array}$ & $\begin{array}{l}\text { IPG Photonics } \\
\text { (Oxford, MA) }\end{array}$ & $\begin{array}{l}\text { IPG Photonics needs a way to run } \\
100-\text { hour unattended burn-in tests } \\
\text { on a } 2-k w \text { laser. }\end{array}$ & $\begin{array}{l}\text { - Fiber lasers } \\
\text { - Laser power and } \\
\text { wavelength measurement } \\
\text { - Laser safety } \\
\text { - Laser beam collimation }\end{array}$ \\
\hline $\begin{array}{l}\text { Shining Light on } \\
\text { Infant Jaundice }\end{array}$ & $\begin{array}{l}\text { Photodigm, Southern } \\
\text { Methodist University } \\
\text { Drexel University, Onsite } \\
\text { Neonatal Partners and } \\
\text { (Richardson, TX, Dallas, } \\
\text { TX, and Philadelphia, PA) }\end{array}$ & $\begin{array}{l}\text { Can technology provide a safe } \\
\text { and effective portable home } \\
\text { treatment for newborn jaundice? }\end{array}$ & $\begin{array}{l}\text { - LED spectral output } \\
\text { - Irradiance } \\
\text { - Scattering } \\
\text { - Absorption spectra }\end{array}$ \\
\hline Watt's My light? & $\begin{array}{l}\text { California State } \\
\text { Polytechnic University at } \\
\text { Pomona } \\
\text { (Pomona, CA) }\end{array}$ & $\begin{array}{l}\text { The package says a } 26 \text { watt } \\
\text { fluorescent has the same light } \\
\text { output as a } 100 \text { watt } \\
\text { incandescent. Can Cal Poly } \\
\text { Pomona students verify this? }\end{array}$ & $\begin{array}{l}\text { - Radiometry and photometry } \\
\text { - Spectral output of light } \\
\text { sources } \\
\text { - Optical power measurement } \\
\text { - Integrating spheres }\end{array}$ \\
\hline Of Mice and Penn & $\begin{array}{l}\text { University of Pennsylvania } \\
\text { McKay Orthopaedic } \\
\text { Research Laboratory } \\
\text { (Philadelphia, PA) }\end{array}$ & $\begin{array}{l}\text { Can optics provide a non-contact } \\
\text { non-destructive measure of the } \\
\text { cross sectional area of mouse } \\
\text { tendons for medical research? }\end{array}$ & $\begin{array}{l}\text { - Geometric optics } \\
\text { - Reflection } \\
\text { - Laser micrometers } \\
\text { - CCD cameras }\end{array}$ \\
\hline
\end{tabular}

Table 1. The PHOTON PBL Challenges

After a problem had been agreed upon, the PHOTON PBL team visited the company or university for a oneor two-day production meeting. At the initial meeting, the PBL team provided an overview of problem-based learning and the goals of the PHOTON PBL project. A tour of the facility followed, recorded on video to provide students with a look at the environment where the problem was solved. In a few cases, the video that resulted was of high enough quality to be edited and included as a tutorial in the completed Challenge. To produce the actual Challenge video, engineers, scientists and technicians at the partner organization were asked to reenact the original introduction of the problem, being careful to include specific details and any constraints necessary to guide students' problem solving efforts. For example, for the PhotoMachining Challenge, Stripping with Light, Fantastic!, a PBL team member posed as a customer who needs fine copper 
wire stripped and cut to length for an implantable medical device. The type of wire and coating and finished dimensions are specified, but the problem parameters are otherwise undefined.

Following the problem statement, the partner technical team was asked to recreate the brainstorming session where they discussed possible solutions. To add a bit of realism, the technical staff was asked to bring a change of clothing to give the impression that the problem and brainstorming were taking place on separate days. The brainstorming discussion provides several hints that might guide a student toward a solution, but the exact details of the solution are not revealed. In the PhotoMachining discussion, for example, two engineers talk about using either an excimer or $\mathrm{CO}_{2}$ TEA laser and that in the past they used some sort of mask for a similar job. They discuss the need for a beam delivery system (but give no details) and that they will need a method to advance the wire, cut it, and check the quality of the final product. In addition to guiding students toward the solution, the brainstorming discussion emphasizes the teamwork skills necessary to be successful in industry. The videos clearly show the technical staff referring to their laboratory notebooks, reinforcing the importance of record keeping and communication skills.

Finally, the PBL team recorded the organization's solution to the problem so that students would be able to compare and contrast their own solutions. Each company visit resulted in several hours of video and a few hundred still photos. Originally, the intent was to create short video segments by editing the original video, but inadequate lighting and the hum of machinery in most industrial settings made that impractical. Instead, the video was edited and transcribed and a script was developed using the actual words of the participants wherever possible. Videos were created from the still photographs with a voice-over-still-photo technique. Voice actors - PBL team members, their family, students and friends - provided the audio. Using video effects such as pan-and-scan (the "Ken Burns effect" available in Apple's iMovie HD) and interspersing actual video footage effectively created the "feel" of the location where the problem was solved.

The partner organizations also helped to locate additional video, print and web resources for students to use in the solution of the problem, including documents describing the organization solution, relevant data and web links. The draft Challenges were reviewed for technical accuracy by representatives of the organization before being field-tested by PHOTON PBL teacher/faculty participants.

\subsection{Components of a Challenge}

Originally, the PBL team planned to create a PowerPoint template that could be easily adapted to new Challenges. However, as the project progressed it was evident that only a web-based format would allow the password protection necessary to allow teachers to control the flow of information. In the final implementation, each PHOTON PBL Challenge consists of five main sections with embedded video (Figure 2). Challenge presentation is preceded by an overview slide that provides a brief description of the problem and a list of photonics concepts addressed. The five main sections are:

1. Introduction - An overview of the particular photonics topic to be explored

2. Company/University Overview - An introduction to the organization that solved the problem to set the context of the problem

3. Problem Statement - A re-enactment of an authentic real-world photonics problem as originally presented to the organization's technical team

4. Problem Discussion - A re-enactment of the brainstorming session engaged in by the partner organization's technical team

5. Problem Solution - A detailed description of the organization's solution to the problem

The Problem Discussion and Problem Solution sections are password protected; teachers are provided with the passwords. This feature gives students the opportunity to brainstorm and test their own solutions while providing a safety net in the event that they become stuck and need further direction. Each of the five main sections contains additional information and resources (video scripts, websites, spec sheets, and so on) designed to guide the student through the problem-solving process. The Problem Solution section resources include summaries of the organization's solution with details such as drawings, calculations and comments from the organization technical team. 

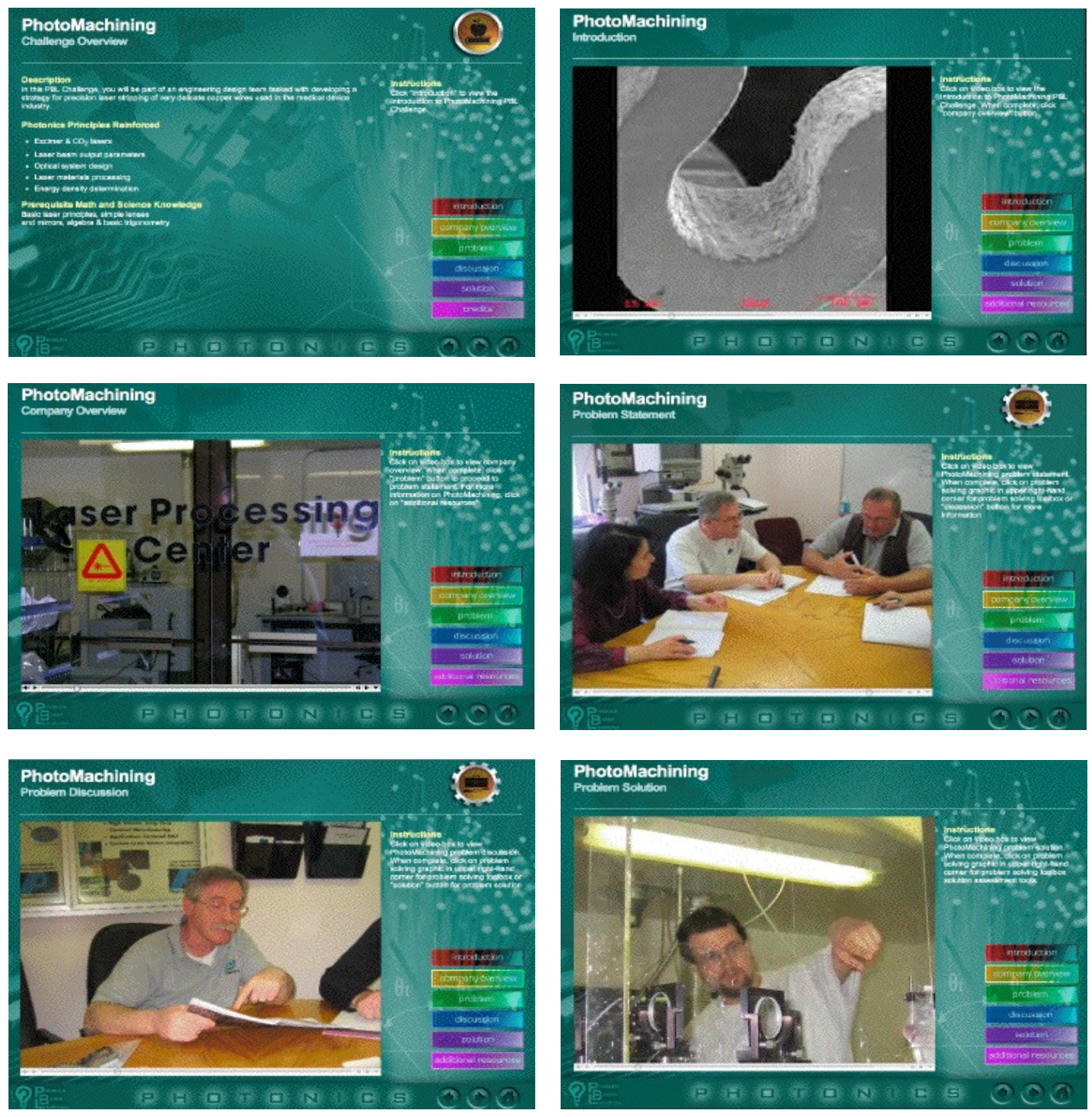

Figure 2. PBL Challenge sections. Top row: Challenge Overview, Challenge Introduction. Middle row: Organization Overview, Problem Statement. Bottom row: Brainstorming Discussion, Organization's Solution.

\subsection{Resources for Problem Solving}

Most high school and community college students do not have a great deal of experience solving open-ended problems and expect to simply sit in class writing down the information delivered by their instructor, returning it in much the same form at a later time on a test or quiz. PHOTON PBL participating instructors, including the authors, report that students' first reaction to the PBL Challenges is often confusion and dismay - a blank stare and "Now what do we do? We don't know anything yet!" To ease students' entry into problem-based learning, the PHOTON PBL challenges include a unique resource, the Problem Solvers Toolbox, to guide students' creative thinking and provide a framework for solving open ended problems.

The Problem Solvers Toolbox (see Figure 3) is reached by clicking on a Toolbox icon on both the Problem Statement and Problem Discussion sections. It is designed to help students develop a systematic approach to problem solving. The four-stage recursive process includes: 
Problem Analysis - Identifying what is known, what needs to be learned, and any problem constraints Self-Directed Learning - Setting specific learning goals, identifying necessary resources, and developing a timeline for achieving those goals

Brainstorming - Productively engaging in collaborative learning to identify the best course of action for solving the task at hand

Solution Testing - Developing a plan to validate the solution based on specific performance criteria

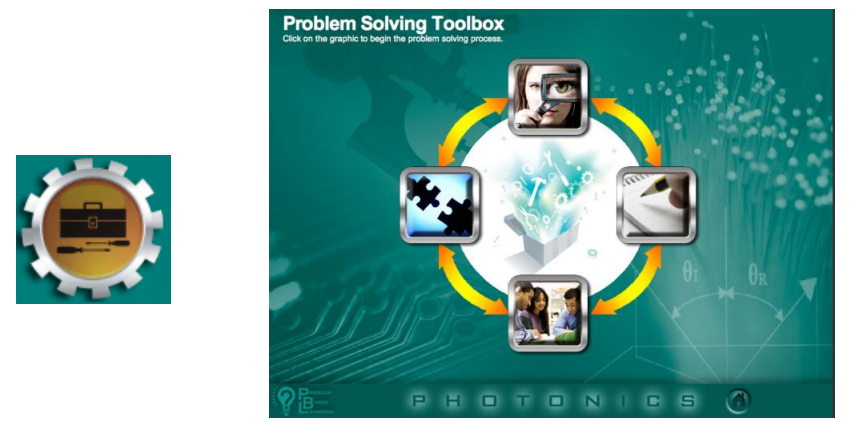

Figure 3. (left) The Toolbox help icon. (right) Problem Solving Toolbox with icons representing Problem Analysis, Self Directed Learning, Brainstorming Discussion and Solution Testing

Clicking on each of the cycle's icons reveals a "whiteboard" graphic designed to emulate an actual classroom whiteboard (Figure 4). The whiteboards help students systematically capture their thoughts, ideas, and learning strategies during each stage of the problem solving process. Students may cycle through the whiteboards several times for a given problem, revising their problem solution each time until they converge on an optimal solution. For instructional purposes, the whiteboards can be projected onto an actual classroom whiteboard using an LCD projector.
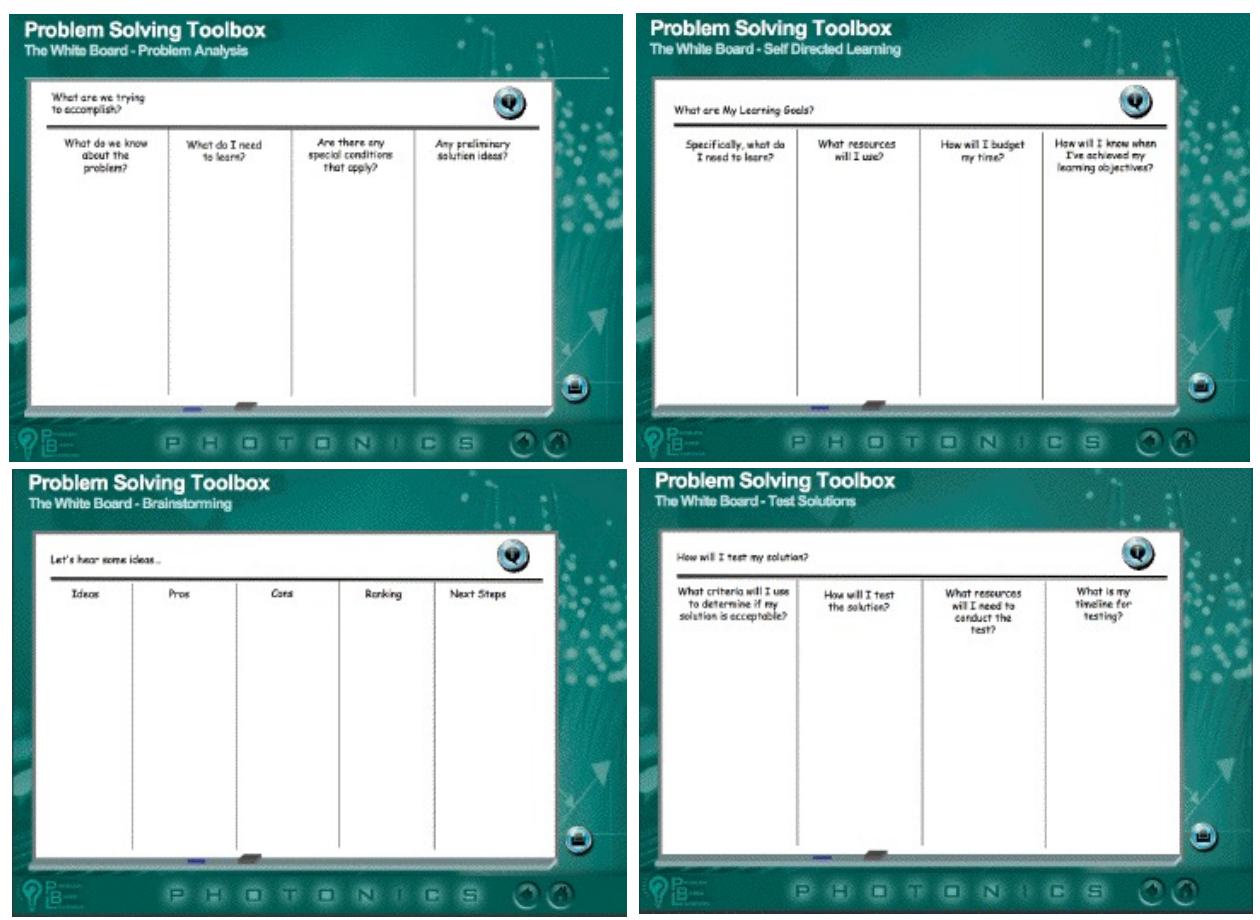

Figure 4. The PHOTON PBL white boards for (top row) Problem Analysis, Self-Directed Learning, (bottom row) Brainstorming, Testing Solutions. 


\section{IMPLEMENTATION}

\subsection{The Three-Level Model}

One issue with pure problem-based learning is that its implementation can be very stressful both for students who are used to passively listening to lectures and for teachers who are perhaps reluctant to give up "control" of the learning environment. To ease the transition from traditional instruction to PBL, the PHOTON PBL team developed a three level approach, allowing teachers to reveal only as much information as needed depending on the technical requirements of the problem and problem solving ability of the students. Figure 5 illustrates the PHOTON PBL three-level model, ranging from structured (instructor-led) to guided (instructorguided) to open-ended (instructor as consultant).

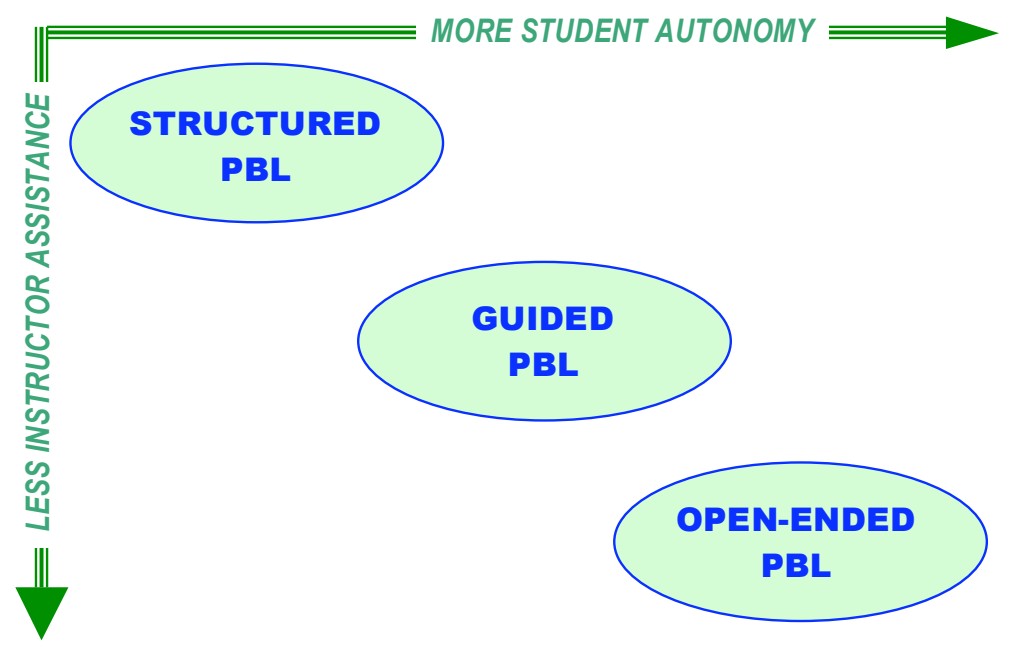

Figure 5. The PHOTON PBL three-tiered approach to problem-based learning

Given the variations in course schedules at different institutions, the PHOTON PBL Challenges are designed to be implemented in one or more 3-hour time blocks per week to conform to the traditional 3-hour weekly lab sessions common in most college technology curricula. This allows the Challenges to be incorporated into most curricula as a supplementary laboratory activity. The following example illustrates how the challenges might be implemented at each of the three levels (structured, guided, and open-ended) in a college setting.

\section{Structured Challenge (Instructor Led)}

Estimated Time for Completion: One 3-hour class + 1-hour follow-up

Used for students with no PBL experience and/or limited technical background. This approach is essentially an interactive multimedia case study. A structured challenge can be introduced in one 3hour lab period with follow up review during the next class.

\section{Guided Challenge (Instructor Guided)}

Estimated Time for Completion: Two 3-hour classes + 1-hour follow-up)

Once introduced to the PBL process using the structured approach, students can progress to the guided approach. The guided approach is similar to the structured approach, but student groups work with limited instructor supervision and are provided more time to develop a more complete solution. The instructor acts as a facilitator to ensure that students stay on track, but refrains from providing solutions or answers to specific questions. This strategy is intended to further develop students' problem solving and critical thinking ability by providing a greater level of autonomy, but at the same time providing a safety net so that learning occurs without risk of failure. Once students have 
presented their solutions to their peers for review, the Problem Solution video is shown, allowing students to compare their solution to the organization's solution.

\section{Open-Ended Challenge (Instructor as Consultant) \\ Estimated Time for Completion: Three 3-hour classes +1 hour follow-up}

In the open-ended approach, students are presented with the most realistic representation of the problem, as it would be encountered in the real world. In the open-ended approach, students are provided only with information from the Introduction, Company/University Overview, and Problem Statement, and are tasked with researching and developing their own solutions without the benefit of viewing the Problem Discussion. The instructor acts as a consultant, providing hints or clues on request, but for a price (e.g., points deducted from a mock budget). Only after student solutions have been presented in a mock design review are the Problem Discussion and Problem Solution revealed. Student solutions are then compared and contrasted with the industry/university solutions in a group discussion and recommendations for improvements are explored.

By allowing students to gradually progress through the PBL Challenges along a developmental continuum, we believe students will be more likely to develop the knowledge, skills, and confidence to take responsibility for their own learning.

\subsection{Teacher resources}

To assist teachers in making the transition to problem-based learning, each PHOTON PBL challenge includes a Teacher Resources section accessed through password protected link on the Challenge Overview screen. Teacher resources include:

Technical background - scientific and technical information related to the challenge

Assessment strategies - assessing student performance on the Challenges

Implementation stories - how other teachers used this Challenge

Standards alignment - how the Challenge addresses content in the national academic standards

Since many of the participating teachers and faculty in the PHOTON PBL project do not have optics/photonics backgrounds and/or experience, the technical background document provides basic information on the science and technology involved in the problem. In some cases email correspondence with the technical team at an organization is included, providing additional detail on the organization's thought process and final solution. Each technical information document includes a warning that this information is not to be shared with students who are in the process of solving a Challenge, although it may be used in discussions after student solutions have been presented.

Teachers who field-tested the Challenges in their own classrooms submitted feedback to the PHOTON PBL team through emailed reports or on a dedicated discussion board in an online Blackboard ${ }^{\circledR}$ course site. This information was used to modify the Challenges and it is also summarized in Challenge-specific implementation stories, allowing teachers to learn through the experience of their peers. For example, some high school teachers expressed a need to modify the Challenge delivery to accommodate the diverse student population in their classes and offered alternate tools for evaluating student performance.

Although each state in the U.S. has its own educational standards, a set of national standards exists in key content areas. Since teachers need to be able to show their school administrators how instructional materials will assist students in meeting the standards, the teacher resources for each Challenge include a standards alignment link. The standards alignment document details how the Challenge addresses the National Science Education Standards (science as inquiry and science content), and the National Standards for Technological Literacy and Mathematics.

A concern of many teachers implementing PBL in their classrooms is "how do I assign a grade?" Unlike traditional tests that have right and wrong answers, problem-based learning is about more than just "getting 
an answer." The PHOTON PBL assessment tools are adapted from research-based strategies for assessing student performance in problem-based learning that include content knowledge, conceptual knowledge, and transfer of knowledge and skills to new situations (problem-solving strategies). ${ }^{5}$

Content knowledge is assessed through traditional means: end of chapter problems, tests and quizzes. The Teacher Resource section of each challenge includes a question bank that can be used for this purpose. Conceptual knowledge may be assessed through creation of a concept map, that is, a graphical tool used to organize knowledge and show relationships between concepts (Figure 6). Concepts may be provided by the instructor, chosen by the students based on their own learning and problem solution or some combination of the two. A sample concept map and a scoring rubric are included in the Teacher Resources for each Challenge. Finally, problem-solving ability may be assessed through a report on the process used to solve the Challenge, as detailed in the students' completed whiteboards. A final technical report form summarizing the whiteboard information and a scoring rubric are included in the Teacher Resources.

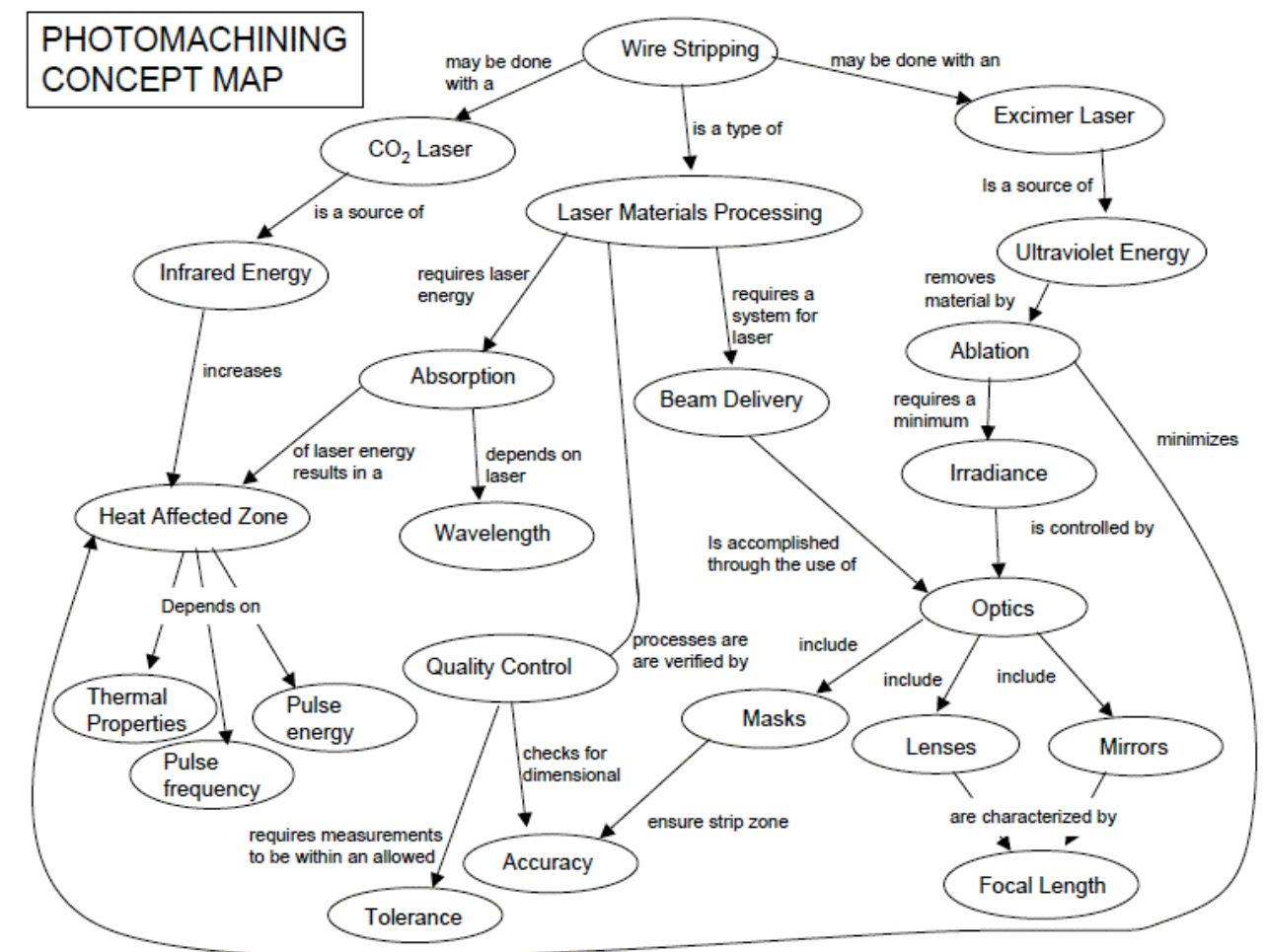

Figure 6. Sample concept map from the Stripping with Light, Fantastic! PHOTON PBL Challenge

In addition to the resources found within each challenge, a complete guide for using the Challenges was developed to accommodate the needs of educators who were not part of the original project as well as to provide a refresher for participating teachers. The pdf document, PBL Challenge Implementation Guide, is an introduction to the PBL method and a complete step-by-step guide to using the PHOTON PBL challenges, including information on the placement and identification of icons and links within the Challenges, suggested timing for problem delivery, and instructions on assessment. The flow diagram in Figure 7 is included in the guide to illustrate the implementation process and the three-level structure of the challenges.

\subsection{Using the PHOTON PBL Challenges in the classroom}

To date, 19 science, technology and mathematics teachers from 11 high schools and 8 two and four year colleges in the U.S. and Romania reported that they field-tested seven of the eight PHOTON PBL Challenges. 
(The final challenge will be released for testing in late spring 2009.) The teachers and their students provided feedback to the PHOTON PBL team through survey forms at the completion of each field-tested Challenge. The participant reports will be used to both refine the Challenges and conduct research on the efficacy of the method. Results of a pilot study designed to examine the efficacy of assessment strategies are reported elsewhere. ${ }^{6,7}$

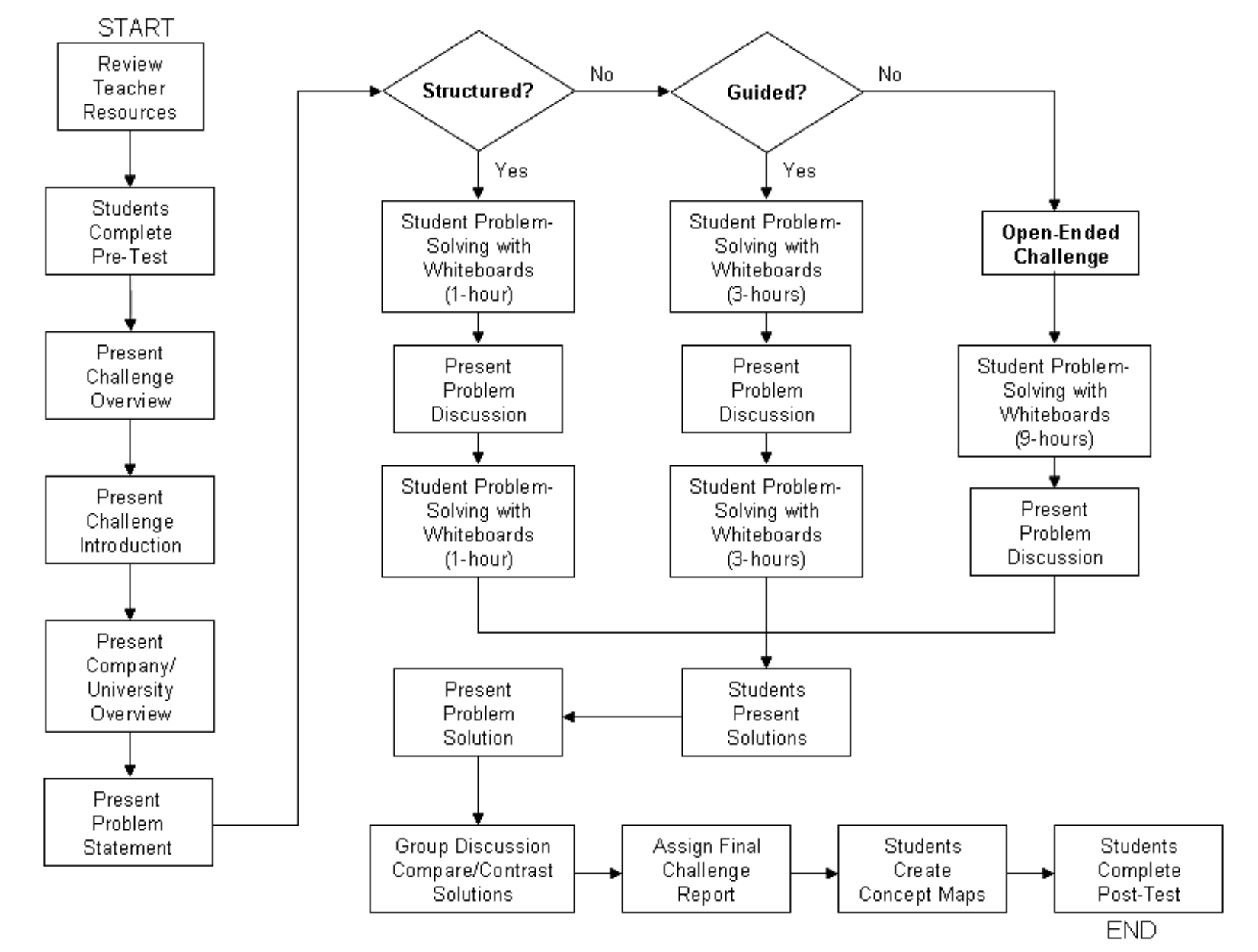

Figure 7. PHOTON PBL Challenge Implementation Flow Diagram

Teachers who used the Challenges generally report that students were engaged and motivated by the Challenges. High school teachers were more likely to report problems with student motivation than college teachers; this was not unexpected since high school classrooms typically include a wider variety of skills, abilities and interests. Students reported that they felt they learned more by solving a problem than by reading about it or listening to a lecture. Comments from students included: "It was good that you could think outside the box for a solution, without having to have only one way to solve it." and "Enjoyed collaborating with teammates, which made it feel like you were working with fellow coworkers on a real problem." Some students also commented that the PHOTON PBL problems were more realistic than the back-of-the-chapter problems they were usually assigned. These students expressed a desire to continue solving PBL challenges rather than return to taking notes on instructor lectures.

Teachers also report that students who become adept at the problem solving method introduced in the Challenges continue to use it in other courses and situations and in some cases introduce other students to 
the PBL white boards. Students gain confidence in their own critical thinking ability and are more likely to try to figure out a problem than to immediately ask for instructor assistance.

\section{Conclusion}

The Photon PBL project, a three-year National Science Foundation Advanced Technological Education (NSF/ATE) project developed a series of multimedia problem-based learning Challenges in optics and photonics and trained science, technology and mathematics educators from across the US and abroad in their use. The classroom presentation of the Challenges may be tailored to the technical knowledge and problem solving ability of students. Resources to assist students in problem solving and to guide teachers in implementation are included in the web-based Challenge platform. Field-testing high school teachers and college faculty report student improvement in student problem solving ability and critical thinking skills with the instructional method.

\section{References}

[1] Savery, J. R., \& Duffey, T. M., "Problem-based learning: An instructional model and its constructivist framework," In B. G. Wilson (Ed.), Constructivist learning environments: Case studies in instructional design, Englewood Cliffs, NJ: Educational Technology Publications (1996).

[2] Zubaidah, S., "Problem-Based Learning: Literature Review", Singapore Nursing Journal, 32 (4), October-December (2005), pp 50-54.

[3] www.faa.gov, Federal Aviation Administration

[4] www.laserist.com, the International Laser Display Association

[5] Pandy, M. G., A. J. Petrosino, Austin, B. A. and Barr, R. E. (2004). "Assessing Adaptive Expertise in Undergraduate Biomechanics." Journal of Engineering Education 93(3): 211-222.

[6] Massa, N.M., Dischino, M., Donnelly, J.F. \& Hanes, F.D. "Problem-Based Learning in Photonics Technology Education" SPIE Optics and Photonics, Volume 7061, pp. 70610S-70610S-13 (2008).

[7] Massa, N.M., Dischino, M., Donnelly, J.F. \& Hanes, F.D, "Problem-Based Learning in Photonics Education: Assessing Student Learning", ETOP Proceedings, 2009.

\section{Acknowledgements}

FOTEP

Funded in-part by the Advanced Technological Education program of the National Science Foundation (\#ATE 9553762). Principal Investigator, Nicholas Massa, Springfield Technical Community College; Co-Principal Investigators Fenna Hanes (Project Manager), New England Board of Higher Education; James Masi, Western New England College; David Maack; Consultant Elias Awad, Wentworth Institute of Technology.

\section{PHOTON}

Funded in-part by the Advanced Technological Education program of the National Science Foundation (ATE \#ATE 0053284) Principal Investigator, Judith Donnelly, Three Rivers Community College; Co-Principal Investigators Fenna Hanes (Project Manager), New England Board of Higher Education; John Swienton, Exfo USA, Inc.; Senior Personnel Nicholas Massa and Barbara Washburn, both Springfield Technical Community College.

\section{PHOTON2}

Funded in-part by the Advanced Technological Education program of the National Science Foundation (ATE \#ATE 0302528) Principal Investigator, Fenna Hanes (Project Manager), New England Board of Higher Education; Co-Principle Investigators, Judith Donnelly, Three Rivers Community College; Marijke Kehrhahn, Neag School of Education (University of Connecticut); Nicholas Massa Springfield Technical Community College.

\section{PHOTON PBL}

Funded in-part by the Advanced Technological Education program of the National Science Foundation (ATE \#ATE 0603143) Principal Investigator, Fenna Hanes (Project Manager), New England Board of Higher Education; Co-Principal Investigators Judith Donnelly, Three Rivers Community College; Nicholas Massa Springfield Technical Community College; Richard Audet, Roger Williams University. Website: http://www.photonprojects.org. 